\title{
The Role of Anti-Corruption Education in the Light of Aristotelian Concept of Akrasia: An Epistemic Inquiry into the Anti-corruption Initiatives in Kenya
}

\author{
Dr. Wycliffe Amukowa \\ Economic Policy and Education Research Centre (ECO-PERC) \\ New Jersey, USA \\ kwamukowa@yahoo.com \\ Prof. Samson 0. Gunga \\ Department of Educational Foundations \\ University of Nairobi \\ qungasamson@googlemail.com
}

Doi: 10.5901/mjss.2013.v4n4p353

\section{Abstract}

This paper undertakes an epistemic investigation of the efforts to combat corruption in Kenya in the light of Aristotle's concept of Akrasia, and proposes a model for educational practice for the purpose of facilitating the fight against corruption. Akrasia is taken to mean a lack of command over self, leading one to act against one's better judgment that one ought to choose virtue against vice.

Key Words : Aristotle, Akrasia, Corruption, Ethics, education, Kenya

\section{Introduction}

There have been efforts to tackle corruption in Kenya for almost six decades now. The Prevention of Corruption Act (Cap.65) was in_operation from August 1956 to May 2003, when the Anti-corruption and Economic Crimes Act No.3 of 2003 became operational. Besides, according to Kenya Anti-Corruption Commission (KACC, 2004), in 1998, the Kenyan Parliament established the Parliamentary Anti-Corruption Select Committee with three mandates: to study the nature and extent of corruption in Kenya, identify the key perpetrators of corruption in Kenya, and develop a more comprehensive Act to widen the scope of the definition of corruption beyond Cap 65 of 1956 and subsequent amendments thereto. Furthermore, according to KACC (2005), Kenya became the first country to ratify the United Nations Convention against Corruption (UNCAC) on $9^{\text {th }}$ December 2003. Kenya is also a signatory to the African Union Convention on the Prevention and Combating of Corruption (AUCPCC) ().

However, several reports show that there is no significant reduction in cases of graft in the country. For example, during the months of August and September 2007, the Kenya Anti-Corruption Commission (KACC) conducted a survey involving 5,207 respondents spread across the country to measure perceived corruption. The survey findings showed that more than three quarters of the respondents $(77.9 \%)$ understood corruption to mean giving and taking bribes. Other manifestations of corruption recognized included misuse of public resources, tribalism/nepotism/favouritism, extortion, fraud, illegal acquisition of public property, and tax evasion. Over three quarters of the respondents (77.6\%) perceived corruption to be a major problem, while nearly all respondents $(91.8 \%$ and $83 \%)$ believed that "grand" and "petty" corruption were equally harmful to the economy (KACC 2008, 69).

Furthermore, according to the survey (KACC 2008), 44 percent of the respondents believed that the level of corruption within public institutions had decreased, 34.3 percent were of the view that it had increased, while 16 percent felt it had not changed. This means that $50.3 \%$ of the respondents were of the view that there was no reduction in levels of corruption. Respondents perceived the Police (Traffic, Regular and Administration) and the Provincial Administration as top in the list of public agencies most involved in bribery. Government hospitals, local authorities, national registration personnel, Lands office, the judiciary and the Department of Immigration were also perceived as dens of corruption. 
Moreover, in the middle of the last decade, Kenya remained in the bottom $10 \%$ of Transparency International's Corruption Perception Index (CPI), an indicator that she was one of the world's most corrupt countries (Transparency International 2006). Besides, according to Transparency International (2009), Kenya was ranked 144 countries for corruption, and was the most corrupt country in East Africa.

This paper suggests a a much richer account of moral obligation based on the gap between knowledge and action such that were the proposed model implemented, the need to address corruption at the statutory level should eventually fall by the wayside. As a result, the Anti-Corruption Education model proposed is not merely one more arm of the anticorruption campaign currently in place but it is, in fact, a completely different way to approach the proble_m in Kenya. It examines the various anti-corruption initiatives in the country, and proposes a model for educational practice for the purpose of facilitating the fight against corruption. It utilizes the critical, analytic and speculative methods of philosophising. The 2007 KACC survey is set forth as a main indicator that current Anti-Corruption initiatives in Kenya are ineffective.

The ineffectiveness of such anti-coruption initiatives, in turn, serves as evidence for the timeliness and relevance of an Anti-Corruption Education model. However, there are some limitations of the survey: First, the survey included 5,207 respondents; however, Kenya's population in 2007 was approximately 36 million, meaning the survey included approximately 100th of 1 percent of Kenya's population. Considering the survey is concerned with the perception of corruption, such a small sample size may call into question whether current Anti-Corruption initiatives in Kenya are as ineffective as the survey would indicate. Nonetheless, this survey provides a jumping-off point for this discussion, and an Anti-Corruption education model would be successful even if Anti-Corruption initiatives in Kenya were successful.

The paper is divided into three main sections. The first section focuses on the history of anti-corruption legislation in Kenya, while the second examines akrasia. Theorization of Akrasia is a speculative approach whose acceptability could be disputed by a skeptic. However, given that Aristotle's theorization of Akrasia plays a guiding role towards the development of an educational model, elements of skeptic nature may not necessarily affect the application of the model.The third and last section of the paper endeavours a development of an anti-corruption education model.

\section{The History of Anti-corruption Legislation in Kenya}

\subsection{The Prevention of Corruption Act Cap.65 of 1956}

Anti-corruption initiatives and establishment of related institutions in Kenya can be traced back to The Prevention of Corruption Act (Cap.65 of 1956). The Act was primarily to be enforced by the Police Department. Despite its existence, corruption grew over the years. Efforts were made to establish an Anti-corruption squad within the Criminal Investigation Department of the Kenya Police, but the squad was disbanded before it could have any significant impact. The Act was amended in 1987 to provide for the establishment of the Kenya Anti-corruption Authority (KACA) to fight corruption, taking this function away from the police. Its formation was a tacit admission of the problem of corruption in Kenya at that time. According to Kibwana and Akivaga (2001), KACA investigated and proceeded to prosecute a number of public officials alleged to have engaged in corrupt practices as defined by the Act.

Part 2 of the Prevention of Corruption Act (Cap.65 of 1956) and subsequent amendments established the Kenya Anti-Corruption and Economic Crimes Board to work with the Kenya Anti-Corruption Authority (KACA). The principal functions of the board were to advise KACA on the exercise of its powers under the Act, and to approve the acceptance of grants and donations to KACA. The Economic Crimes Court was also established under the Prevention of Corruption Act Cap.65 of 1956 and subsequent amendments. It exercised unlimited jurisdiction in respect of crimes under the Act itself. The Act vested power in KACA's officers to conduct investigations, obtain information necessary for presentation before the court, effect arrest for offences under the Act, and intercept private information upon an ex parte application to the court. However, in December 2000 (High Court of Kenya 2003), the High Court in the case of Gachiengo vs. Republic (2000) ruled that the existence of KACA undermined the powers conferred on both the Attorney General and the Commissioner of Police by the Constitution of the Republic of Kenya. Consequently, KACA was disbanded.

\subsection{The Anti-corruption and Economic Crimes Act 2003}

The object of the Anti-Corruption and Economic Crimes Act 2003 was to provide for the prevention, investigation and punishment of corruption, economic crimes and related offences and incidental matters. The Act embodied a broad conception of corruption viz.bribery, fraud, embezzlement or misappropriation of public funds, abuse of office, and breach 
of trust or an offence involving dishonesty in connection with any tax, rate or impost levied under any Act (Republic of Kenya 2003, Section 45).

Part II of the Anti-Corruption and Economic Crimes Act 2003 provided for the appointment of special magistrates with exclusive jurisdiction to try offences specified in the Act. They were obliged, as far as was practicable, to hold the trial of an offence under the Act on a day-to-day basis until completion. Part III A of the Act established the Kenya AntiCorruption Commission (KACC) as the premier institution for fighting corruption in the country, vested with a wide mandate to investigate corrupt conduct, trace and recover corruptly acquired public property, devise corruption prevention mechanisms and educate the public on the dangers of corruption. Part III B established the Kenya Anti-corruption' Commission Advisory Board as a corporate body independent and answerable only to Parliament. The Board was to advise the Kenya Anti-Corruption commission generally on the exercise of its powers and the performance of its functions under the Act. Further, it was to recommend to parliament persons to be appointed and/or removed from office as Director and Assistant Directors of the Commission, and to approve grants and donations to the Commission.

However, on August 24th 2011, Parliament passed the Ethics and Anti-Corruption Commission Act 2011, effectively repealing the Anti-corruption and Economic Crimes Act 2003, thereby disbanding the Kenya Anti-corruption Commission.

\subsection{The Ethics and Anti-Corruption Commission Act 2011}

Pursuant to Article 79 of the Constitution of Kenya 2010, the Ethics and Anti-Corruption Commission (EACC) was established by the Ethics and Anti-Corruption Commission Act No.22 of 2011 (Republic of Kenya 2011). The Act mandates the Commission to, inter alia, develop and promote standards and best practices in integrity and anticorruption; oversee the enforcement of codes of ethics prescribed for public officers; monitor the enforcement of codes of conducts of members of professional bodies established under any law; advise, on its own initiative, any person on any matter within its functions; raise public awareness on ethical issues, educate the public on the dangers of corruption, and enlist and foster public support in combating corruption ; work with other State and public offices in the development and promotion of standards and best practices in integrity and anti-corruption measures, and receive complaints on the breach of the code of ethics by a public officer. The Act further provides that the Commission shall investigate and recommend to the Director of Public Prosecutions the prosecution of any acts of corruption or violation of codes of ethics or other matters prescribed under this Act or any other law enacted pursuant to Chapter Six of the Constitution.

\section{Theorization of Akrasia}

As noted at the outset, the various anti-corruption initiatives in Kenya have not significantly reversed the spread of the vice. Perhaps anti-corruption initiatives in the country could begin with the acknowledgement of humankind's apparent inability to attain moral perfection. Human beings have a tendency not to adhere to the conduct that they set to govern their behaviour, a condition which philosophers refer to as akrasia (Amukowa 2010, 150). Below we explore this condition, with a view to getting deeper insight into the tension, so commonly experienced among humankind, between knowing the good and doing the good.

\section{Aristotle's Theorization of Akrasia}

\subsection{The Dilemma of Akrasia}

Aristotle (2000) holds that akrasia presents a special challenge to moral education, as it is a form of practical judgment that has gone astray. He argues that the belief that Akrasia connotes ignorance is mistaken, because incontinents do possess knowledge of the good, and to achieve correct knowledge they must be exercising reason. For Aristotle, akrasia has been wrongly defined as abandonment of reason, and to assume that it occurs in the face of appetite or pleasurable feelings is equally incorrect. Nonetheless, he declares:

...these common beliefs should not be discounted... while neither is entirely correct; each does contain a key insight regarding akrasia. The second premise is that the right to maintain that appetite is central to incontinence. What it fails to consider is the possibility that appetite is central to continence as well ... appetite is not the villain in the drama of akrasia. Its role must be explained in another way (Aristotle 2000, 232ff). 
Furthermore, Aristotle holds that it is right to assume that correct reasoning leads to correct behaviour. However, he observes that this fails to entertain the possibility that reasoned judgment can conflict with a person's actual conduct. In Aristotle's view, it is precisely the conflict between reason and behaviour which makes akrasia so puzzling:

Though persuaded to act otherwise ... the incontinent still acts wrongly. The incontinent person thinks it is wrong to pursue ... the pleasant thing at hand, yet still pursues it (Aristotle 2000, 275).

Exploring common beliefs about incontinence thus leads Aristotle to ask two questions that bring the dilemma of akrasia into focus:

How is it possible for the akratic to arrive at correct conclusions, yet still act wrongly?

What role do feelings and appetites play in the puzzle of akrasia?

Aristotle considers two reasons to explain why knowledge and action conflict. The first reason, Aristotle (2000, 280ff.) says, derives from the fact that correct reasoning requires both universal and particular premises. Individuals, however, sometimes attend to one premise at the expense of the other. Concentrating exclusively on the universal premise leads to incorrect conduct, because it is the particular premise which controls action:

Correct classification cannot take place without the universal premise, for it is the universal premise which articulates general concepts and categories. In so far as the universal premise is ignored, then, mis-classification is likely. Incorrect classification of the particular, in turn, results in incorrect action (Aristotle 2000, 261).

The second reason, for Aristotle, why knowledge and behaviour sometimes conflict does not concern the knowing process, but rather the conditions under which knowledge is achieved. Individuals may possess knowledge, but they also may be "asleep or mad or drunk." It is this second state of affairs which for Aristotle best describes akrasia. Like those who are asleep or mad or drunk, the incontinent is affected by strong feelings:

Such persons both have knowledge in a way and do not have it ... people affected by strong feelings may say knowledgeable things ... this does not mean, however, that these persons actually understand the words they espouse. In this respect, the incontinent is like an actor who can convincingly recite verses even though he does not comprehend them, or a young learner who is able to string together words without fully grasping their meaning (Aristotle 2000, 283 ff.).

The central question thus comes into view: how, precisely, do appetites and strong feelings affect the reasoning process when persons knowingly act against their better judgment? Aristotle offers the following explanation: suppose that someone has (a) the universal belief, and it hinders him from tasting; he has (b) the second belief, that everything sweet is pleasant and this is sweet, and this belief (b) is active; and he also has appetite. Hence the belief (c) tells him to avoid this, but appetite leads him on, since it is capable of moving each of the (bodily) parts. The result, then, is that in a way reason and belief make him act incontinently. The belief (b) is contrary to correct reason (a), but only coincidentally, not in itself. For it is the appetite, not the belief, that is contrary (in itself to correct reason). From this explanation, Aristotle concludes that "... beasts are not incontinent, because they have no universal supposition but (only) appearance and memory of particulars" (Aristotle 2000, 293).

\subsection{The Two Levels of Knowledge as a Basis of Understanding Akrasia}

Aristotle (1952) contends that the incontinent person enacts principles that are good. Such a person assents to follow them, but fails to do so. Both the incontinent and the wicked person do what is wrong. However, the wicked person rationalizes such actions, while the incontinent person does not. Aristotle argues that the actions of a wicked person emanate from choice, but the incontinent acts not by choice, but contrary to his/her choice and judgment. Normally the incontinent person has the intention to do that which is right. However, faced by the choice between pleasant and harmful things, the incontinent fails to act on the good judgment or principles that he or she enacted. Aristotle maintains that "...incontinent men are at variance with themselves [and]... usually have appetites for some things and rational desires for others" (Aristotle 1952, 1166). He argues further that the incontinent person possesses a rational principle which is supposed to influence his or her choice towards things that are for his or her own good. However, appetites oppose this 
rational principle. The incontinent consequently performs that action which is contrary to the desires of the rational principle.

Aristotle explains incontinence as resulting partly from the conflict between the principles in the Soul. For him, when the appetitive principle overcomes the rational principle, the incontinent person loses the capacity to do that which is consonant with his/her enacted principles. The incontinent person usually regrets his or her actions. Consequently, he or she is curable of his or her weaknesses, but the wicked person is not:

There is no cure for that person who does not regret his errors. The incontinent man knows that what he does is bad. He is therefore conscious, unlike the wicked person who is unconscious of his wickedness (Aristotle 1952, 1146).

Having distinguished the wicked person from the incontinent one, Aristotle conceptualizes akrasia with regard to knowledge, that is, that a person can have knowledge and act against it:

... an incontinent is a person who has knowledge yet he acts against such knowledge. Such a person has knowledge because he is not oblivious of the general principles that he has enacted. Knowledge is awareness of what one is required to do (Aristotle 1952, $1166 \mathrm{ff}$.).

According to Aristotle, there are two senses in which a person may be said to know something, as there are two senses of the word know. One may have knowledge without using it, or one may have knowledge and use it. There is nothing strange in saying that an incontinent person has knowledge of the former sense. However, saying that what he is doing is knowledge at work is absurd (Aristotle 1952, $1246 \mathrm{ff}$.).

In Aristotle's distinction between the two senses of "Know" lies a postulation of the difference between potentiality and actuality. Potentiality is a foundation to those states and forms that can be achieved or realized. Potentiality is realized only if effort is forthcoming. On the other hand, actuality is the realization of the desired states and forms. It is a reality of a capacity inherent in a given thing. As earlier noted, Aristotle explains that the knowledge that an incontinent man has is like that of a man who is asleep or drunk (Aristotle 1952, $1116 \mathrm{ff}$.).

As we earlier Noted, Aristotle contends that the main reason why a person may fail to act in a way consonant with the knowledge that he/she has lies in the non-translation of universals or general principles to particulars. Aristotle explains:
... particulars are individuals while universals are types. The particulars may be understood in the two senses of knowledge as distinguished earlier. Knowledge of the particulars is specific while knowledge of the universals encompasses generalities. Universal means belonging to, done by all or affecting all (Aristotle 2000, $1125 \mathrm{ff}$.).

In Aristotle's view, the two levels allow the non-translation of knowledge into action by agents. A person may act against these professed principles. This may result from the failure to see the action at hand as falling under the said principles. It is therefore not absurd to say that a person acts against this knowledge:

There is nothing to prevent a person having both premises and acting against his/her knowledge, provided that he/she is using only the universal premise and not the particular for it is the particular acts that have to be done (Aristotle $1952,1146 \mathrm{ff}$.$) .$

\subsection{Contemporary Perspectives on Akrasia}

According to Audi (1995), much of the philosophical literature takes akrasia to be the same thing as weakness of the will. Holton (1998) sees weakness of the will as a tendency to revise one's judgment about what is best too easily. Christopher (2004) argues that incontinence or weakness of the will occurs when someone consciously or deliberately makes a choice that he/she sincerely believes is wrong. For Njoroge (1988), cases of akrasia occur when both of the conflicting elements are readily available to consciousness. He argues that when people behave akratically, they are often aware of what they are doing. Thus the incontinent smoker is fully conscious of her resolve to give up her habit just as she reaches out for another cigarette. Akrasia, then, involves conflicts between our evaluations and our commitments, or between our commitments and acts falling under them.

According to Becker (1975), in psychological literature, several models have been proposed to aid the understanding of how behaviour can be changed. These models are a product of psychology, sometimes called the science of behaviour, and more specifically of one of its relatively new fields, the psychology of health. The first model, the Health Belief Model, shows the importance of beliefs in the adoption of behaviour. The notion of motivation, in the 
form of the concept of intention, was introduced by the Theory of Reasoned Action (Fishbein and Ajzen 1975) and the Theory of Planned Behaviour (Ajzen 1985). The Theory of Interpersonal Behaviour (Triandis 1979) introduced the role played by habit. The Self-Regulatory Model showed that a subject's self-evaluation of behaviour creates a situation of feedback, which manifests itself not only at the cognitive, but also at the emotional level (Leventhal 1997).

The Health Locus of Control (Wallston 1978) and the Socio-cognitive Theories (Bandura 1991) highlight the psychological notion of self-efficacy. The Trans-theoretical Model of Change (Prochaska 1983) attempts to explain the adoption of a form of behaviour as a dynamic process, concerned not so much with what leads the subject to a change in behaviour, but rather with how to describe the stages of the change. In the Theories of Reasoned Action and Planned Behavior, the likelihood of adopting a form of behaviour is closely associated with the intention expressed by the patient. In these models, the patient's intention to perform behaviour is a construct combining her attitude toward performing the particular form of behaviour and subjective norms, represented by beliefs, concerning the way the form of behaviour is perceived by persons who may be important to her.

Surprisingly, none of the models above incorporates the concept of weakness of will, given that failure to diet or to refrain from smoking are routinely used by philosophers as examples of paradigmatic cases of weakness of will.

\section{Towards an Educational Model for Anti-Corruption Initiatives in Kenya}

Stewart and Lorber-Kasunic (2008) argue that an ethical curriculum should seek to cultivate in its students not only an ability to recognise what is good and right, but a disposition to hold to that good in practice. Further, they contend that graduates of such a curriculum should be empathetically equipped to recognise particular sources of akrasia. For them, the desire to act sustainably or compassionately can be thwarted by pressures of time, lack of equipment, bad habits or simply exhaustion. The study by Stewart and Lorber-Kasunic (2008) is informative with regard to setting goals and objectives of an ethical curriculum. However, it falls short of proposing what models could be used to impart such desired values.

Pendlebury (2005) investigates whether or not the teaching of ethics can help to make people engage in genuine, non-corrupt business. She asserts that this is not possible, and gives three reasons to support her position.

First, it is erroneous to assume that akrasia is only or primarily a moral problem. A man acting against his own best judgment does not always act immorally. If his best judgment is not in the interest of the good, then his akratic action may in a sense be more moral than an action consistent with his best judgment.

Second, according to Pendlebury (2005), it is a mistake to assume that the only or primary task of moral education is to address the problem of akrasia. She suggests that a central task for moral education today is to "engage everyone involved in defining just what 'the good' means."

Third, for Pendlebury (2005), it is misleading to assume that pluralism is the main reason why it is not easy to know what is right. Practical judgment can go wrong in several ways, not all akratic, and any of which could lead us to act wrongly. For instance, we may do the wrong thing because we are insufficiently attuned to the fine details of a situation, or because we do not always properly know what we are doing. While habituation of the right kind may be crucial in developing those virtues of character which are the mainstay of right action, right action also requires a proper judgment of the situation and of the conflicting concerns that have a bearing on it.

The study by Pendlebury (2005) underscores the role of education in changing people's behaviour with regard to moral obligations. It also gives insights into how people act in accordance with their expectations.

\subsection{The Need to Address the Causes of Akrasia}

According to Kerdeman (n.d.), knowing what is right is an insufficient condition for doing what is right; or, to put the matter more broadly, judging what is in our own best interests (however these are conceived) is insufficient for acting accordingly. An important educational question, then, is how far and in what ways akrasia can be tackled at its source. Kerdeman (n.d.) contends that we act against our own best judgments for many reasons, for instance, because of poor habits of action mismatched with our desires or aspirations; because of lack of the perceptual and imaginative habits required for seeing the preferred goods vividly (or for seeing, in concrete detail, the ways in which and the extent to which the akratic alternative might be damaging); because of a lack of subjective conviction in our own strength or in our own future. All these are instances of how powerlessness, in various forms, tends to akrasia.

From our earlier reflections on Aristotle's theorization of Akrasia, it is our view that there are four elements that could make people act akratically. 
First, a person who usually does not stick to his or her decisions is not authentic. This implies that such a person lacks a quality of sticking to what he or she judges to be good. Sartre says that authenticity has to be earned by an individual. In his words, "my own authenticity only ... under the influence of conscience. I launch out towards death, with resolution and decisions, as towards my own particular possibility" (Sartre 1958, 246). An inauthentic person lacks the seriousness that would make him or her realize his or her potentialities. On the other hand, the authentic person heeds the voice of conscience. The inauthentic one does not heed the voice of conscience. After doing what is contrary to his or her principles, he develops self-blame (Njoroge 1988, 78). Inauthentic people do not believe in themselves. They do not stick to decisions because of self-doubt. As such, they do not persevere in the face of difficulties.

Second, the person who abandons his or her principles lacks attention : other things easily distract him or her. This person lacks concentration on the task at hand, and is easily distracted through lack of self control. Attention with effort is all that any case of volition implies. The essential achievement of the will is to attend to a difficult object (James 1952, 814). As earlier noted, Aristotle explains that the reason why knowledge and behaviour sometimes conflict does not concern the knowing process, but rather the conditions under which knowledge is achieved. These states are characterized by the presence of strong feelings that distract their will from proper judgment and consequent commitment to action, that is, from engaging in the action that is consonant with sound judgment. With regard to the fight against corruption, individuals may fail to pay attention to what is required of them.

Third, although humankind are conceived of as rational, sometimes in the face of difficulties they have a tendency to opt for the easy course of action. If they find that the principle that they have enacted for themselves is difficult to live up to, they choose the easier course of action, even with its inherent evil rather than the hard course of action though perhaps with greater good. Aristotle says that a person who is weak goes through a process of deliberation and makes a choice; but rather than act in accordance with his reasoned choice, he acts under the influence of passion (Aristotle 2000, 1125).

Fourth, the functionality of alternatives presenting themselves to the agent could also be a factor contributing to the abandonment of principles. If, for example, the agent's principle is "I ought not to steal" but money comes into his or her custody by virtue of his employment, he or she may start thinking in terms of what the money could do for him or her. The more he or she is convinced that he or she could become better off than he or she is at present in terms of status, the more he or she may deviate from his or her principle. He or she may eventually choose to steal the money with the consequent effects that stealing entails.

Consequently, with regard to the fight against corruption, an educational model should seek to facilitate the development of a person's capacity towards the realization of authenticity, attentiveness, commitment to principles, and resistance to temptation. This in turn informs the theoretical and practical approached to anti-corruption education as shown in the diagram below. 


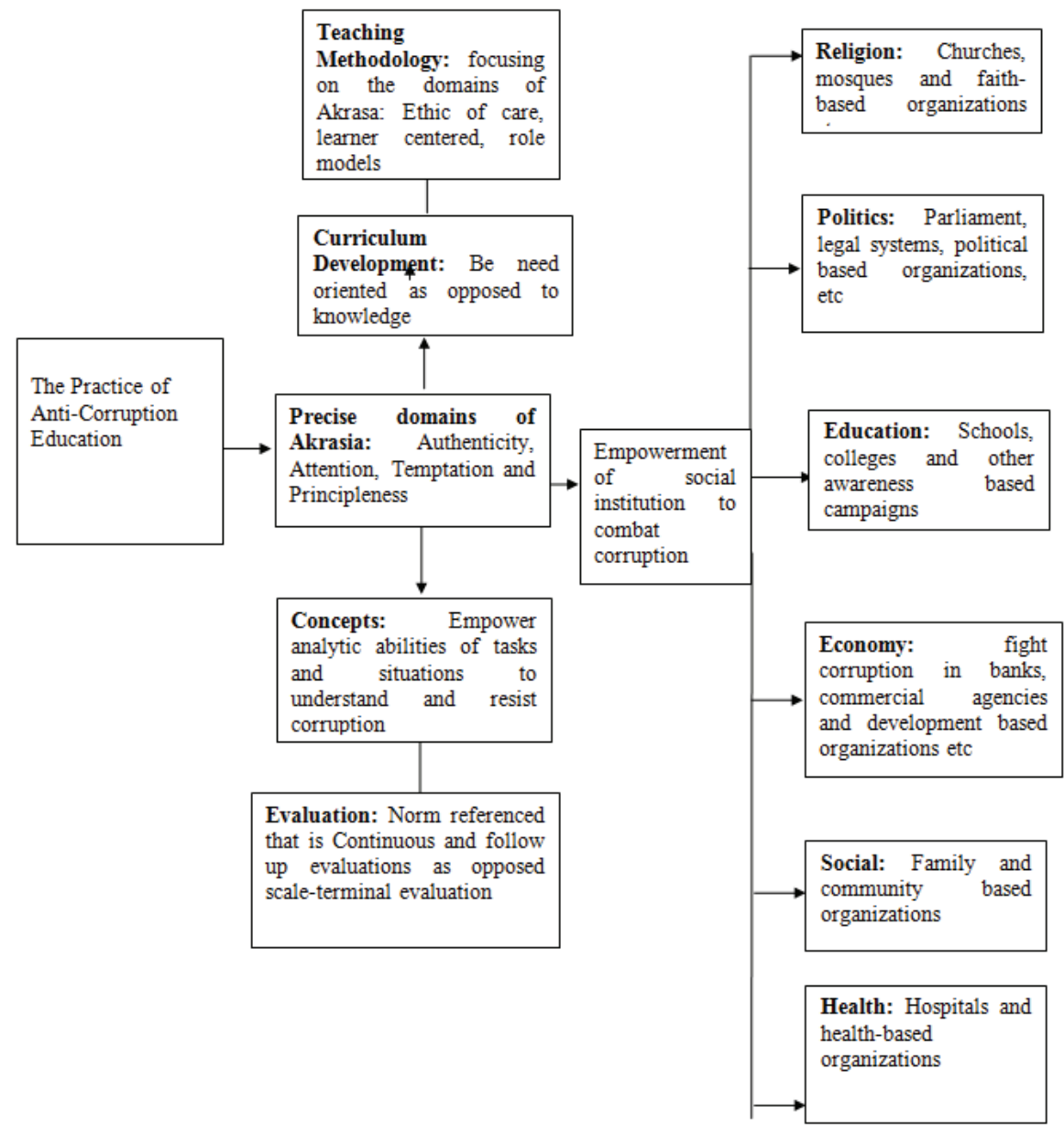

Figure 1: Diagrammatic Representation of an Educational Model for Anti-Corruption Initiatives

The model for the Practice of Anti-Corruption Education that we propose emphasizes an understanding of the Precise domains of Akrasia in shaping people's moral character, namely, authenticity, attention, temptation and commitment to principles. Underscoring the effects of corruption, the model favours a need-oriented curriculum development as opposed to a knowledge-oriented one. Likewise, its teaching methodology should focus on the domains of Akrasia, with emphasis on an Ethic of care, a learner centered approach, and the use of role models. According to Noddings (2002), each person has a set of moral ideals that guide his/her behaviour. People derive these ideals from experiences, encounters, and caring relations with others. Concepts covered should sharpen the learner's analytic abilities in their approach to tasks and situations in order to enable them to better understand and resist corruption. The model also favours norm referenced Evaluation that is Continuous and follow up evaluations as opposed to scaleterminal evaluation.

Furthermore, the model emphasizes the need for Anti-corruption Education to cut across all the social institutions, among which are the family, politics, religion, economy and health, with the aim of fostering the moral well-being of people. Anti-Corruption Education should lead to empowerment of social institutions to combat corruption. This is because corruption occurs across these institutions. With innate moral well-being, people will act with regard to the interests of others (James 1952). 


\subsection{Authenticity, Care and Connectedness}

Throughout the process of moral development, people adopt virtues based on their experiences and societal norms, and their ideals are informed by these virtues. People attempt to live up to their ideals, but they are not always successful. Sometimes the habitual self takes precedence over the ideal self (Noddings 2002); sometimes the ideal self is obscured by the debased ideals of others around (Taylor 2001). People's ideals form part of their self or identity, and all are frequently changing, so it can be difficult to know whether their behaviour, self, identity, and ideals are consistent. Our proposed educational model is based on the conviction that in attempting to behave in ways congruent with moral ideals and ideal self to the best of one's abilities, and in reflecting honestly on these ideals and on one's own behaviour in the context of relations with others, one can be considered authentic.

The morality underlying authenticity is based on the need to care and be cared for, and the desire to reciprocate others' care (Noddings 2002). In this sense, moral behaviour and caring are important components of authentic behaviour, and all authentic behaviour is oriented toward this basic assumption. In this regard, the development of the 'self' (or 'identity') and the moral ideals underlying authentic behaviour require connection, dialogue, and interaction with others. Taylor $(1989,35)$ notes that one is a self only among other selves. A self can never be described without reference to those who surround it. The self is under constant negotiation, development, and change based on experiences, critical reflection and evaluation. Noddings says, "...the self is a relation...it is dynamic, in continual flux" (Noddings 2002, 99). Therefore, the ideal self is a moral construct we strive to live up to in our quest to be authentic: it is "that subset of the self regarded as best" (Noddings 2002, 108).

Noddings (2002) supports the importance of caring and authenticity in education on three counts. First, caring, authentic relations should encourage and cultivate dialogue, questioning, debate, and moral judgment, which are essential components of education. Second, teachers who base this type of encounter on an ethic of care do not attempt to wield power over students or coerce them into accepting certain points of view; rather, they are facilitators to the reflective process. They do not expect to have the answers at the outset, and may learn as much from the process as the students do. Relations in which participants have equal responsibility facilitate learning by allowing students to think for themselves, question their own circumstances, and create their own interpretation of what is moral. Third, there are certain assumptions about what is moral in this framework, and educators must take care to "continually inspect, reflect upon, and revise their own practices and attitudes" (Noddings 2002, 136), and aspire to be as authentic as possible in the light of their role as models for learners.

Similarly, according to Zaltz (2003), learning is most effective when educators and learners share the positions of "carer" and "cared-for" in the learning environment. Caring relations become paramount as each is called upon to trust the other, examine their own beliefs and actions, and support each other during this process. Just as caring relations are necessary to promote dialogue and self-reflection among friends or family, so are they necessary to promote the same actions between educators and learners of all ages.

The fundamental aim of education is to help learners to grow in desirable ways. This is best accomplished by modelling, dialogue, practice, and confirmation. Modelling is very powerful, and it appears as a component in almost every form of moral education. To be effective it must be genuine; that is, an exemplar must not consciously exhibit one form of behaviour in the presence of the learners, and then - caught off guard - act in a way that contradicts what he or she has modelled. Modelling may be more effective in the moral domain than in the intellectual, because its very authenticity is morally significant (Noddings 2002, 287).

While this process primarily refers to moral learning, caring relations may also facilitate academic or formal classroom learning. Teachers who care about their students and model authentic behaviour make students feel respected, trusted and worthwhile. As a result, students may be more motivated to take part in the learning process, knowing that their participation will be recognized and appreciated. According to Vygotsky (1978), if learning is a social and cultural process, establishing a caring culture in a classroom would enable learning to occur more effectively. In certain situations, cooperative or mediated learning can often accomplish far more than individual learning: effective cooperation and mediation rely on trust and personal connection, which can be established more easily within an ethic of care.

According to Bai \& Chinnery (2000), the more strongly one is interconnected with the world, the more deeply and reliably one responds to it in showing compassion and good will. Thus the prerequisite for responsibility is cultivation and realization of inter-being. From inter-being, responsibility naturally emanates:

If we consider "the world" ... to be the relationship between the teacher and student, the stronger the connection between the teacher and student, the more likely the student is to respond in the educational environment. Similarly, we 
can consider "the world" to mean the classroom or learning environment, so that the student, through experiencing interconnectedness with other students, is motivated to show compassion and good will to classmates. With enough experiences like these, students may extend their compassion and good will habitually to others outside the classroom as well. This feeling of interconnectedness could only be fostered by an authentic educator (Bai \& Chinnery 2000, 9).

Educators must demonstrate and encourage students to understand that we require fundamental connections in order to realize our selves and identities. This will encourage students to participate in democratic society, value the common good, and see themselves as part of a community. In this way, educators can discourage students from adopting undesirable character and the prevalent fixation with self-fulfillment and personal freedom. In this regard Bai \& Chinnery (2000) note :

\footnotetext{
... it is only through caring that requires self-reflective participation of the self in the other...that the self overcomes its private egoist intention and orientation (Bai \& Chinnery 2000, 7).
}

The model so developed emphasises that the fight against corruption is a universal moral obligation. Anticorruption Education should emphasize the moral development of the people, rather than merely making them aware of the effects of corruption and why it should not be tolerated. This model is based on the understanding of Anti-corruption Education as the activity of strengthening knowledge, skills and attitudes necessary to enable the learner to resist unethical behaviour in the public sphere. Its goal is to build demand for accountability. It promotes values that condemn corruption, and skills to resist it. In sum, it develops people's understanding of their rights and responsibilities for promoting the public good.

\subsection{Attentiveness and Commitment to Principles}

Addresses commitment to principles and resistance to temptation is especially relevant in light of the 2007 KACC survey, which serves as the backbone of y paper. Survey participants were asked to identify the causes of corruption in Kenya; greed was identified as the leading cause ( $65 \%$ of respondents), followed by poverty (the survey indicates over $50 \%$ of Kenya's population lives in poverty), and high levels of unemployment.

Peter et al (2012) observed that Intentions to do better and less bad are reliably associated with actual efforts in the intended directions. However, the link between intention and behavior is modest, largely due to the fact that people, despite having formed strong intentions, fail to act on them. Given this predicament, one wonders what people can do to facilitate the translation of intentions into behavior. This paper argues that, the person who abandons his or her principles lacks attention: other things easily distract him or her. This person lacks concentration on the task at hand, and is easily distracted through lack of self control. For this reason, Anti-corruption Education Model proposed in this paper underscores the need for people to be trained in achieving self-control.

According to (Carver \& Scheier, 1982) Control Theory postulates that self-regulation is a process of comparing the current rate of goal progress (input) against the desired rate of goal progress (reference value) and acting on discrepancies as and when they arise (output). Baumeister et al (1994), self-control is a product of (1) social norms and standards according to which individuals should behave, (2) self monitoring and attention to one's own behaviors (i.e. comparing oneself to the standards), and (3) the individual's ability to alter his or her own behaviors (i.e. the capacity to change one's behaviors and conform to the standards). Problems in one (or more) of these ingredients leads to low selfcontrol. Specifically, Baumeister et al. (1994) contend that conflicting sets of standards, the inability to monitor selfbehaviors, and inadequate strength of self-stopping (i.e. the ability to exert both mental and physical resources in order to override impulses, habits or some other tendency) contribute to an individual's low self control which results in an individual's inability to control the major domains of the self, and leads to crime.

Elaborating on the causes of self control, Gottfredson and Hirschi (1990) contend that low self control is a relatively stable trait established during childhood, and that it is the product of ineffective child rearing and ineffective socialization by parents. Specifically, these authors contend that in order to teach the child self control, someone must monitor the child's behaviors, recognize deviant behavior when it occurs and punish such behaviors. Thus, a parent who cares for his/her child supervises and monitors the child's behaviors, and corrects him when recognizing deviant or dangerous acts. Parents who fail to follow these child rearing practices encourage the development of the child's low self control.

This paper contends that the practice of anti-corruption education should start at family level. At the moment, anticorruption initiatives approaches have taken top-bottom approach, in which the government through its agencies has taken over the initiatives. However, in order to ensure that people exercise self-control as discussed in this paper, there is 
need for paradigm shift and adopt a bottom-top approach in which the need for to fight and discount corruption starts from the family level to the government agencies. This way, parents should be empowered and encouraged to mould their children to self-control.

Gottfredson and Hirschi (1990) observed that Self-control is best realized when there is a social control mechanism within the community. Social control theories suggest that the underlying process that narrows individuals' tendencies to engage in crime are strong bonds to society. According to Durkheim (1897 [1951]), behaviors are the product of social integration and regulation. Social integration is the intensity of the collective life that circulates within a social aggregate. Accordingly, the more active and constant the intercourse among its members, the more powerful and unified is social integration. Regulation, on the other hand, is a social mechanism aimed at restraining the savage side in human nature. Society's inability to exert regulation upon its members may result in a breakdown of standards and values (Durkheim 1951).

Hirschi (1969) propounded that all humans are motivated toward deviance but only those who are relatively free of the bonds of conventional order and social institutions actually translate their deviant motivation into illegitimate behaviors. Weak or broken social bonds to society are considered by Hirschi (1969) as the primary reason for individuals' deviance and crime. According to Hirschi, members in society form bonds with one another (for instance parents, friends, co-workers) as well as with social institutions (churches, schools). These social bonds evolve due to social ties and affection that develop between individuals and key people in their lives; commitment to social norms of behavior; involvement in social activities; and belief in and respect for the law. By establishing social bonds, individuals generate higher levels of social capital and internalize the norms of society. Deviance and crime in this sense are perceived as the consequences of individuals' failure to form social bonds and generate social capital.

The Anti-Corruption developed in this paper has called for the institutions of the society to work together. In particular, it mentions religious, health, political and economic institutions facilitate the need to eradicate corruption. This way, the model calls for the training of personnel in all the institutions as well development of curriculum materials to achieve this goal. The proposed model takes note of the fact that approaches used in knowledge dissemination are not the same. For example, the framework for teaching in schools is not the same as that used in the church, hospital or family. The proposed model calls for development of teaching and learning materials unique to every institution that would form part of a strengthened social control with regard to the fight against corruption.

This paper noted that although humankind are conceived of as rational, sometimes in the face of difficulties they have a tendency to opt for the easy course of action. If they find that the principle that they have enacted for themselves is difficult to live up to, they choose the easier course of action, even with its inherent evil rather than the hard course of action though perhaps with greater good. Aristotle says that a person who is weak goes through a process of deliberation and makes a choice; but rather than act in accordance with his reasoned choice, he acts under the influence of passion (Aristotle 2000, 1125). This implies that people may discount self-control in the event that they find sticking to the values they have enacted.

According to (Loewenstein, 1996), people face a self-control problem when they perceive a conflict between the short-term and long-term outcomes of an action while Rachlin (1996) observed that in general, unfulfilled immediate wishes and desires are the short term costs of pursuing long-term goals. Short-term costs may thus pose a threat to longterm goals. This way, Counteractive control theory (CCT) posits that self-control efforts serve to overcome such threats. Yaacov and Fishbach (n.d) point out that this short-term costs affect action via two paths). Directly, these costs act to decrease the likelihood of acting according to long-term goals. Indirectly, however, short-term costs elicit counteractive control efforts, which, in turn, act to increase the likelihood of this action. As a result, the actual choice of a preferred action may remain unaffected by its short-term costs.

According to Yaacov and Fishbach (n.d) CCT assumes that people exert counteractive control efforts as means to the end of achieving their long-term goals. Three hypotheses follow from this means-end assumption: First, counteractive control is goal dependent. People will exert more counteractive control when short-term motives threaten important rather than unimportant long-term goals. Furthermore, once a long-term goal is achieved, counteractive control will cease. Second, counteractive control is flexible. Counteractive control will be exercised when it determines whether or not longterm goals will be achieved. Little or no counteractive control will be exerted when short-term motives are weak and thus easy to resist or very strong and thus impossible to resist. Greater counteractive control will be exerted when the strength of short-term motives is at an intermediate level, because at this level counteractive control determines whether long-term goals will be achieved. Third, counteractive control is substitutable. Counteractive control will be exerted when it is necessary for achieving one's long term goals. When other, external means of control are in place, counteractive selfcontrol will cease. 
Anti-Corruption Education Model is tied on a wide range of self-control strategies have proposed from studies on delay of, implementation of intentions and control over impulsive behavior. Yaacov and Fishbach (n.d) distinguish between strategies that change the choice situation and those that change the subjective meaning of the situation. People may change the choice situation in several ways: They may impose on themselves penalties ("side bets") for failing to act according to their long-term goals (Ainslie, 1975; Becker, 1960). These self-imposed penalties may then serve as external deterrents against failure to pursue long-term goals. Yaacov and Fishbach (n.d) give the example below:

For example, one may be willing to pay a relatively large cancellation fee for missing a painful medical test. By itself, the expected pain increases the likelihood of failing to actually take the test and having to pay the cancellation fee. Simple economic considerations (minimizing expected monetary penalties) should therefore lead people to impose on themselves a relatively small fee to the extent that the medical test is more painful. CCT predicts, however, that the more painful a test is expected to be, the higher the cancellation fee people will be willing to pay. Yaacov and Fishbach (n.d:748)

Another way in which people may change future choice situations as argued Yaacov and Fishbach (n.d) is by making rewards contingent upon acting according to their long-term interests. Instead of receiving a reward unconditionally, people may prefer to receive it only if they act according to their long-term interests. For example, people may prefer to receive a bonus for actually completing a painful but subjectively important medical test rather than for merely agreeing to do it. By making penalties and rewards contingent on performing an activity, people pre-commit themselves to the activity People may pre-commit themselves more directly by eliminating action alternatives and thus making a decision to act according to their long-term interests irreversible(Brickman, 1987).

Other counteractive control strategies change the psychological meaning of future choice situations (Yaacov and Fishbach, n.d). People may selectively attend to, encode, and interpret information about future situations so as to bolster the value of long-term goals and discount the aversiveness of short-term costs. According to Bandura (1989) the value of long-term goals may be enhanced by linking the attainment of these goals to self-standards. Failure to pursue long-term outcomes is then construed as a violation of one's values and a threat to one's sense of self-worth and determination. In addition, people may bolster the value of attaining long-term goals by elaborating upon what makes attainment of these goals important. Yaacov and Fishbach (n.d) give the example below:

\begin{abstract}
In trying to decide whether to undertake a medical test, people may think of how undertaking the test may help them detect and prevent potential health problems. Counteractive control may also aim to discount short-term costs. People may try to attenuate the anticipated aversiveness of short-term costs by focusing on the abstract, "cool" properties of these costs rather than on their concrete, "hot". People may also try to regulate their mood so as to improve their ability to cope with short-term costs. For example, people may seek mood-enhancing experiences to buffer the anticipated unpleasantness of a medical procedure Yaacov and Fishbach (n.d:749)
\end{abstract}

From the theorization on Self-Control, Social Control and Counteractive control, the proposed model of AntiCorruption Education vitalizes the role of every institution of the society in facilitating its members to remain committed to their principles and being attentive when performing their moral tasks. The enactment of anti-corruption laws and punishments, regardless of how severe the punishment may be, may not yield effective anti-corruption strategy. In a situation where people do not have a capacity to have several control, hence not sticking to their principles or losing attention, such behaviour seems involuntary. It is an act emanating from a poorly developed person and so it is facilitated by lack of something and not the presence of something. This translates to an understanding that corruption indicates absence of a virtue, and not the presence of a vice. To address this gap, Anti-corruption should focus on the development of virtue and not eradication of a vice.

\title{
5.4 Dealing with Temptations
}

From the theorization of Akrasia, this paper argues that alternatives presenting themselves to the agent could also be a factor contributing to the abandonment of principles and temptation. If, for example, the agent's principle is "I ought not to steal" but money comes into his or her custody by virtue of his employment, he or she may start thinking in terms of what the money could do for him or her. The more he or she is convinced that he or she could become better off than he or she is at present in terms of status, the more he or she may deviate from his or her principle. He or she may eventually 
choose to steal the money with the consequent effects that stealing entails. This implies that there is need to reduce opportunities that may lead into corruption. To this end, lessons may be taken from the Situational prevention approach.

According to Clarke (1997), Situational prevention comprises opportunity-reducing measures that (1) are directed at specific forms of crime; (2) involve the management, design or manipulation of the immediate environment in as systematic and permanent way as possible, (3) make crime more difficult and risky, or less rewarding and excusable as judged by a wide range of offenders. Cornish and Clarke (1988), point out that Situational prevention has several features: First, it makes clear that situational measures must be tailored to highly specific categories of crime, which means that distinctions must be made between the different kinds of offenses. Clarke (1997), argues that the need to tailor measures to particular offenses should not be taken to imply that offenders are specialists - only that the commission of specific kinds of crime depends crucially on a constellation of particular environmental opportunities and that these opportunities may need to be blocked in highly specific ways.

In the analysis of Cornish and Clarke (1988), the second important feature of the definition of situational prevention is the implicit recognition that a wide range of offenders, attempting to satisfy a variety of motives and employing a variety of methods, may be involved in even highly specific offenses. It is further recognized that all people have some probability of committing crime depending on the circumstances in which they find themselves. The third point deriving from the definition is that changing the environment is designed to affect assessments made by potential offenders about the costs and benefits associated with committing particular crimes. These judgments dependent on specific features of the objective situation and determine the likelihood of the offense occurring. This implies some rationality and a considerable degree of adaptability on the part of offenders.

According to Cornish and Clarke (1988), recognizes, fourth, that the judgments made by potential offenders include some evaluation of the moral costs of offending. We may all be prepared to steal small items from our employers, but few of us would be willing to mug old ladies in the street. Not all offenses are equally reprehensible, even in the eyes of the most hardened offenders. This means that making it harder to find excuses for criminal action may sometimes be an effective opportunity-reduction technique. It also means that differences in the moral acceptability of various offenses will impose limits on the scope of displacement.

The Anti-corruption Education Model proposed appreciates the fact that institutions of the society need to have capacity to secure and seal loopholes that may lead to corruption. This calls for an empowered society in which people have knowledge to detect and prevent corrupt behaviour. It should then be the task of Anti-corruption education to develop such capacities through knowledge sharing and skills development. Members of community based organization, civil societies, politicians and religious groups would be better placed in chatting the way forward. This way, there should be a need oriented curriculum towards community empowerment with regard to anti-corruption initiatives.

\subsection{The Curriculum Content for Anti-Corruption Education}

The practice of anti-corruption education should cut across all the levels of learning. The approach requires a need driven curriculum. The content should be structured alongside the learner's ability to internalize and practice it. The content should focus on the development of the innate capacities of the learner, so as to guide his or her behaviour when faced with a moral decision. It should also help the learner to actualize the moral good. In this regard, Anti-corruption education can be integrated in school subjects such as civics or citizenship education, but also history, politics, religion, life skills, peace education, economics or ethics. Although most of the curricula may not explicitly refer to the fight against corruption, they are all implicitly linked to it. This is due to the fact that they touch on moral issues and deal with concepts such as the public good and social justice that are key to understanding the need to fight corruption. The fight against corruption can, of course, also be taught outside the formal school system (Valentine, Juhie, Katy, Julio 2004, 23).

\subsection{Teaching Methodology of the Anti-Corruption Education}

Teachers of anti-corruption education should be well-equipped with requisite knowledge, skills and attitudes in order to effectively preside over the delivery of content to the learners. The teaching approach should take into account the cognitive level of learners and their ability to benefit from such methodology. The exercise of responsible judgement is at the heart of professional activity, and the actions of caring, competent and committed teachers and other education personnel to help every student actualise his or her potential are critical in the provision of quality education (The Fourth World Congress of Education International, 2004). In this regard, an anti-corruption education model that underscores the following steps would make solid contributions towards efforts to eradicate corruption. 
First, a central focus of ethics training should be to strengthen individual moral autonomy. With more selfassurance, individuals are more likely to address ethical dilemmas and make decisions in line with an organization's ethical framework. A necessary point for any ethics training programme is to establish a common understanding of existing attitudes and values. A participatory "cultural audit" can be conducted to learn more about current ethical perceptions and practices within a particular organization, and this can also contribute to an increased sense of ownership of ethics training programmes. Audits can be conducted in a number of ways - including via the study of documents, through focus-group discussions, and through organization-wide surveys.

Second, there is need to compare existing attitudes and values with the overall aspirations of the society. Following this analysis, the objectives of the training campaign must be set. These may be to help learners understand what is meant by corrupt behaviour, or to develop ways to articulate and encourage attitudes that support ethical practice (for example awards for outstanding ethical behaviour).

Third, the key messages of the training programme must be defined and an appropriate means of delivering them chosen. Methods for communicating ethical messages can include posters, brochures, audio-visual material and ethics workshops. Role-play and case-study discussions are often effective training methods, but should be customized for the particular target-groups involved.

\subsection{The Language of Anti-Corruption Education}

Anti-Corruption education should help the learners to understand the meaning of concepts used in the fight against corruption. This calls for an analysis of concepts, that is, the clarification of the meaning of key concepts used in discourses about the fight against corruption. The basic guideline for language selection should be the ability of the learners to grasp and apply such concepts in a morally desirable manner.

\subsection{Evaluation of Anti-Corruption Education}

There should be constant evaluation of the anti-corruption education programmes to get feed back on areas that need improvement. Evaluation should further be undertaken to test the learners' understanding and application of what has been taught. This way, practical observation of task performance, coupled with the principles of criterion evaluation would be more desirable than norm-referenced evaluation. This is because moral tasks cannot be evaluated in terms of percentage scores. For example, it does not always follow that a learner who scores the highest mark in an examination would be the best behaved. Such a learner could have memorized the lesson for the sake of passing the examination, and not as a show of commitment to moral obligations.

\section{Conclusion}

It is often taken for granted that with knowledge of how to act coupled with an expressed acceptance of the execution of the said action, people will act as desired. This, however, as argued in this paper, does not always obtain. Indeed, transmission of knowledge does not always translate into action. This reveals a gap between knowledge and action. Consequently, anti-corruption initiatives need to acknowledge humankind's apparent inability to actualize perfection.

More specifically, Anti-corruption Education should build people's capacity to be conscious and attentive at all times when discharging their obligations. This could be done through the laying of emphasis on professional ethics and codes of regulation rather than focusing on the issue of corruption. Anti-corruption Education should concentrate on building humankind's innate rational capacity and ability to withstand temptation. Such education should also help people to develop capacities necessary for sealing off avenues of corruption.

\section{References}

Adler, Jonathan. 2002. "Akratic Believing". Philosophical Studies, Vol.110 No.1.

Ajzen, I. and M. Fishbein. 1980. Understanding attitudes and predicting behavior. Englewood Cliffs, NJ: Prentice-Hall.

Amukowa, W. 2010. "A Critique of Kenya Anti-Corruption Commission's Initiatives in Combating Corruption and its Implications for Education in the Light of Aristotelian Concept of Akrasia". Unpublished PhD Thesis at the University of Nairobi.

Aristotle. 2000. Nicomachean Ethics. Crisp, Roger Trans. Cambridge: Cambridge University Press.

(1952): "Nicomachean Ethics" Published as: Aristotle's Essay On The Nature Of Ethics Great Books of the Western World, Vol. 9. Chicago: Encyclopedia Britannica/University of Chicago Press. 
Audi, Robert(ed). 1995. Cambridge Dictionary of Philosophy. Cambridge: Cambridge University press.

Bandura, A. (1989). Self-regulation of motivation and action through internal standard and goal systems. In L. A. Pervin (Ed.), Goal concept in personality and social psychology (pp. 19-85). Hillsdale, NJ: Erlbaum.

Baumeister, R. F., Heatherton, T. F., \& Tice, D. M. (1994). Losing control: How and why people fail at self-regulation. San Diego: Academic Press.

Becker, Slack M.H. and L.A. Maiman. 1975. The health belief model and personal health behavior. Health Education Monographs, 2(4). Medical Care, 13, 10-24..

Bovens, Luc. 1999. "The Two Faces of Akratics Anonymous". Analysis, Conference of Logic, Methodology and Philosophy of Science, Vol. 2, pp.230-236.

Bradley, F. Herbat. 1962. Ethical Studies. Oxford: Clarendon Press.

Brickman, P. (1987). Commitment, conflict, and caring. Englewood Cliffs, NJ: Prentice-Hall.

Carver, C. S., \& Scheier, M. F. (1982). Control theory: A useful conceptual framework for personality-social, clinical, and health psychology. Psychological Bulletin, 92, 111-135. Reprinted in R. F. Baumeister (Ed.), (1999), The self in social psychology. Philadelphia, Psychology Press

Clarke, Ronald V. (1997). Introduction. In Clarke, Ronald V. (ed.). Situational Crime Prevention: Successful Case Studies (2nd ed.). (pp. 1-43). Albany: Harrow and Heston.

Cornish, Derek \& Clarke, Ronald V. (1988). "Introduction" in The Reasoning Criminal. Cornish, Derek and Ronald Clarke (eds.). New York: Springer-Verlag. pp 1-16. ISBN 3-540-96272-7

Donald, Davidson. 1969. "How is Weakness of the Will Possible?" Donald, Davidson ed. Essays on Actions and Events. Oxford: Oxford University Press.

Durkheim, Emile. [1897] 1951. Suicide, translated by John A. Spaulding and George Simpson. New York, NY: The Free Press.

Fishbein, M. and I. Ajzen. 1975. Belief, Attitude, Intention, and Behavior: An Introduction to Theory and Research. Reading, MA: Addison-Wesley.

Gottfredson, Michael R., and Travis Hirschi. 1990. A General Theory of Crime. Stanford, CA: Stanford University Press.

High Court of Kenya. 2003. Miscellaneous Criminal Application No.495 of 2003. Nairobi.

Hirschi, T. (1969). Causes of delinquency. Berkeley: University of California Press

Holton, Richard. 1998. The Akratic Behaviour in Man. Cambridge: Cambridge University press.

James, William. 1952. The Principles of Psychology. Hutchins, R.M. ed. Chicago: Encyclopedia Inc.

Jiang, Xianan . 2000. "What Kind of Knowledge Does a Weak-Willed Person Have? A comparative Study of Aristotle and the Ch'engChu School". Philosophy East \& West, Vol.50 No.2, pp.242-253.

KACC (Kenya Anti-Corruption Commission). 2004. Kenya Anti-corruption Commission Annual Report 2003/2004. Nairobi: Kenya AntiCorruption Commission.

--. 2005. Kenya Anti-corruption Commission Annual Report 2004/2005. Nairobi: Kenya Anti-Corruption Commission.

--. 2006. Kenya Anti-corruption Commission Annual Report 2005/2006. Nairobi: Kenya Anti-Corruption Commission.

--. 2007. Kenya Anti-corruption Commission Annual Report 2006/2007. Nairobi: Kenya Anti-Corruption Commission.

--. 2008. Kenya Anti-corruption Commission Annual Report 2007/2008. Nairobi: Kenya Anti-Corruption Commission.

Kerdeman, Deborah. N.d. Educating Ethical Behavior: Aristotle's Views on Akrasia. Washington: University of Washington. www.ed.uiuc.edu/EPS/PES-yearbook/.../KERDEMAN.HTM

Kibwana, Kivutha and S. Kichamu Akivaga 2001. Initiatives against Corruption in Kenya : Legal and policy Interventions, $1995-2001$. Nairobi : Claripress.

Kibwana, Kivutha, Smokin Wanjala and Oketch- Owiti. 2005.( . THIS IS HOW IT IS PUBLISHED, I HAVE IT MY LIBRARY IT IS ALSO AVAILLABLE ONLINE)

The Anatomy of Corruption in Kenya: Legal, Political and Socio-Economic Perspectives (Review) : a case study of the Goldenberg Export Compensation payments. Nairobi : Claripress.

Loewenstein, G. (1996). Out of control: Visceral influences on behavior. Organizational Behavior and Human Decision Process, 65, 272292.

Njoroge, G. Kanari. 1988. 'Conceptualization of Akrasia in Kenya's Educational Policy'. Unpublished Masters Thesis at Kenyatta University.

Noddings, Nel. 2002. Starting at Home: Caring and Social Policy. Berkeley, California: University of California Press.

Pendlebury, Scott. 2005. Education: A Response to Deborah Kerdeman. Johannesburg: University of the Witwatersrand.

Peter M. Gollwitzer, Ute C. Boyer, Kathleen C. McCulloch (2012). The Control of the Unwanted. University Press Scholarship Online

Prochaska, O. James, and C.C. DiClemente. 1983. 'Stages and processes of self-change of smoking: Toward an Integrative Model of Change'. Journal of Consulting and Clinical Psychology, 51, pp.390-395.

Procter, Paul ed. 1980. Longmans Dictionary of Contemporary English. London: Longman.

Republic of Kenya. 1992. The Constitution of Kenya, Chapter V, Protection of Fundamental Rights and Freedoms of the Individual Section 77: Provisions to Secure Protection of Law, Revised Edition (1998). Nairobi: Government Printer.

--. 2003. The Anti-Corruption and Economic Crimes Act, 2003. Nairobi: Government Printer.

--. 2005. Report of the Public Investment Accounts Committee. Unpublished.

--. 2011. The Ethics and Anti-Corruption Commission Act No. 22 of 2011. www.kenyalaw.org

Rachlin, H. (1995). Self-control: Beyond commitment. Behavioral and Brain Sciences, 18, 109-159. 
Stewart, S.C. \& J. Lorber-Kasunic. 2006. 'Akrasia and the ethical design curriculum'. Davies, A. ed. Enhancing Curricula: contributing to the future, meeting the challenges of the 21 st century in the disciplines of art, design and communication. London : University of Arts, London.

Taylor, Charles. 1989. Sources of the Self: The Making of the Modern Identity. Cambridge, Massachusetts: Harvard University Press.

--. 1991. The Malaise of Modernity. Don Mills, Ontario: House of Anansi Press.

--. 2001. Multiculturalism: Examining the Politics of Recognition. Princeton, NJ: Princeton University Press.

The Fourth World Congress of Education International, 2004. "Resolution on the Role of Education in Combating Mismanagement and Corruption". Meeting held in Porto Alegre, Brazil, from 22 to 26 July, 2004.

.Transparency International (TI). 2006. Corruption Survey Index. Berlin: Transparency International.

--. 2007. Corruption Survey Index. Berlin: Transparency International.

--. 2008. Anti-Corruption Education . www.transparency.org/global priorities/other thematic issues/education/anti-corruption education

--. 2001. United Nations Convention Against Corruption. New York : United Nations.

Valentine, A.J.S., S. Katy and U. Julio. 2004. 'Reducing Incentives for Corruption in the Mexico City Police Force'. International Workshop, Public Affairs 869, La Follette School of Public Affairs.

Vygotsky, Lev. 1978. Mind in Society: The Development of Higher Psychological Processes. Cambridge: Harvard University Press.

Wallston, Kenneth A., Barbara S. Wallston and Robert DeVellis. 1978. 'Development of the multidimensional health locus of control (MHLC) scales'. Health Education Monographs, 6, pp.160-170.

Yaacov and Fishbach (n.d) Self-Control and Situational Control Over Behavior. An unidentfied post on the internet. 